The Voluntary Food Intake of Pigs

Occasional Publication No. 13-British Society of Animal Production 1989

edited by J. M. Forbes, M. A. Varley and T. L. J. Lawrence

\title{
THE USE OF MILK REPLACERS AND THE EFFECT ON SUBSEQUENT PERFORMANCE OF NEWBORN PIGLETS
}

\author{
H. ROYEAERD, H. VAN DER HEYDE, J. P. DE METS and H. K. HENDERICKX
}

State University and Meat Technology, Proefhoevestraat 12, B-9230 Melle, Belgium

\section{INTRODUCTION}

$\mathbf{R}$ obison (1972), Revelle and Robison (1973), Alsing (1976) and Johansson (1980) reported that female animals, originating from large litters, have less reproductive capacity than females coming from small litters. Research in Melle showed that reduction of the litter size as well as early weaning has a positive influence on the reproductive performance of female piglets (van der Heyde, 1983; van der Heyde and Lievens, 1982, 1984a and b). Van der Steen (1985) found that gilts raised in litters, standardized to 12 piglets, produced smaller litters (by 0.48 piglets) compared with those raised in litters, standardized to six piglets. The results obtained suggested that a low standardization level positively affects weaning weight and the development of the uterus of the gilts. Csarnecki, Wejehsza and Owsianny (1986) proved that this positive effect on reproductive performance was not only true for female, but also for male piglets. These facts suggest that post-natal feeding could be very important regarding the subsequent reproductive performance.

A trial was carried out to investigate the effect on growth rate and subsequent reproductive performance of giving to newborn piglets milk replacer ad libitum. At the time of instituting this approach, it was recognized that supplementary feeding during the pre-weaning period might cause a transient hypersensitivity to food antigens in the immediate post-weaning period, leading to changes in the small intestine structure and to diarrhoea (Miller, Newby, Stokes and Bourne, 1984; den Hartog, Verstegen and Everts, 1985; Hampson 1986). At the same time, the use of milk replacers had been shown to reduce mortality and improve growth rates, without any deleterious effects at weaning, in other work (Op de Beck and Castaldo, 1983). Besides this last report, only two other publications (van der Steen, den Hartog, de Grost and de Roo, 1983; van Rijen, 1985) have been found for the period 1980-1988, concerning the influence of intake of milk replacer on growth rate of piglets.

The intake of milk replacer had no significant influence on mortality up to 8 weeks post weaning: $91 \%$ of the piglets reared without milk replacer and $90 \%$ of the piglets reared with milk replacer, survived.

\section{MATERIAL AND METHODS}

Litter size was standardized at nine to 11 piglets and weaning age at 12 days. The performance of 390 Landrace piglets, receiving ad libitum milk replacer during the suckling period, was compared with that of 88 control piglets. A commercial milk replacer (crude protein $210 \mathrm{~g}$, fat $80 \mathrm{~g}$, carbohydrate $500 \mathrm{~g} / \mathrm{kg}$ was provided daily in small cups or in nipple drinkers. After weaning, piglets were reared in cages for 4 weeks at $27^{\circ} \mathrm{C}$ and subsequently 4 weeks at $25^{\circ} \mathrm{C}$. After weaning, piglets received $3 \mathrm{~kg}$ milk replacer powder and a starter diet containing $610 \mathrm{~g}$ barley, $260 \mathrm{~g}$ soya, $90 \mathrm{~g}$ skimmed milk powder and $40 \mathrm{~g}$ vitamins and minerals per $\mathrm{kg}$.

In order to determine the variation in intake of milk replacers, according to their composition, eight commercial milk replacers were compared one by one on the basis of the solubility, the preservation and the level and speed of intake. Crude protein content of these milk replacers ranged from 190 to $250 \mathrm{~g} / \mathrm{kg}$, fat content from 70 to $150 \mathrm{~g} / \mathrm{kg}$ and carbohydrate content from 30 to $50 \mathrm{~g} / \mathrm{kg}$.

\section{RESULTS}

The average weight at weaning and at 4 weeks after weaning, of all piglets reared with milk replacer, was higher than that of the control piglets (Table 1). The average daily growth rate showed the same tendency. However, none of these differences was significant. When growth rate of male and female piglets was analysed separately, there was one significant difference $(P<0.05)$ : male piglets in the group reared with milk replacer grew $397 \mathrm{~g} / \mathrm{kg} v .441 \mathrm{~g} /$ day for the male control piglets, from the age of 4 to 8 weeks post weaning. As male and female piglets were compared within the treatment group and the control group, it became obvious that female piglets especially benefit from the intake of milk replacer (Table 1). Birth weight of female piglets was 0.93 to 0.94 of birth weight of male piglets. Without milk replacer supplementation this difference 
remained up to 4 weeks post weaning. Using milk replacer, this difference disappeared at weaning age; at the age of 8 weeks post weaning, the average weight of the female piglets was 1.08 of the average weight of the male piglets $(P<0 \cdot 01)$. Growth rate showed the same tendency: the female piglets of the control group could hardly catch up their male littermates. As for the group reared with milk replacer, the female piglets grew $12 \mathrm{~g} /$ day better from weaning to 4 weeks after weaning $(P<0.05)$ and $48 \mathrm{~g} /$ day better from 4 to 8 weeks after weaning $(P<0.01)$, compared with their male littermates.

TABLE 1

The effect of intake of milk replacer during the suckling period, on live weight and growth rate of male and female piglets

\begin{tabular}{|c|c|c|c|c|c|c|c|c|}
\hline \multirow[b]{3}{*}{ Weight (kg) } & \multicolumn{8}{|c|}{ With milk replacer } \\
\hline & \multicolumn{3}{|c|}{$\begin{array}{c}\text { Female } \\
(\text { no. }=184)\end{array}$} & \multicolumn{3}{|c|}{$\begin{array}{c}\text { Male } \\
(\text { no. }=206)\end{array}$} & \multicolumn{2}{|c|}{$\begin{array}{c}\text { Total } \\
(\text { no. }=309)\end{array}$} \\
\hline & Mean & s.d. & $\%$ & Mean & s.d. & $\%$ & Mean & s.d. \\
\hline Birth & $1 \cdot 48^{* *}$ & 0.30 & $94 \cdot 3$ & $1 \cdot 57^{* *}$ & $0 \cdot 31$ & 100 & $1 \cdot 53$ & $0 \cdot 31$ \\
\hline Weaning & 3.73 & 0.93 & $100 \cdot 5$ & $3 \cdot 71$ & $1 \cdot 02$ & 100 & $3 \cdot 72$ & 0.98 \\
\hline 4 weeks & $8 \cdot 64$ & $2 \cdot 19$ & $104 \cdot 2$ & $8 \cdot 29$ & $2 \cdot 24$ & 100 & $8 \cdot 45$ & $2 \cdot 22$ \\
\hline 8 weeks & $21 \cdot 09^{* *}$ & $4 \cdot 82$ & $108 \cdot 6$ & $19 \cdot 42^{* *}$ & $4 \cdot 96$ & 100 & $20 \cdot 21$ & 4.97 \\
\hline \multicolumn{9}{|l|}{ Growth rate (g/day) } \\
\hline Birth to weaning & 188 & 56 & $103 \cdot 9$ & 181 & 64 & 100 & 184 & 61 \\
\hline Weaning at 4 weeks & $175^{*}$ & 57 & $107 \cdot 4$ & $163^{*}$ & 58 & 100 & 169 & 58 \\
\hline \multirow[t]{3}{*}{4 to 8 weeks } & $445^{* *}$ & 114 & $112 \cdot 1$ & $397^{* *}$ & 123 & 100 & 420 & 121 \\
\hline & \multicolumn{8}{|c|}{ Without milk replacer } \\
\hline & \multicolumn{3}{|c|}{$\begin{array}{c}\text { Female } \\
(\text { no. }=46)\end{array}$} & \multicolumn{3}{|c|}{$\begin{array}{c}\text { Male } \\
(\text { no. }=42)\end{array}$} & \multicolumn{2}{|c|}{$\begin{array}{c}\text { Total } \\
(\text { no. }=88)\end{array}$} \\
\hline Weight (kg) & Mean & s.d. & $\%$ & Mean & s.d. & $\%$ & Mean & s.d. \\
\hline Birth & $1 \cdot 49$ & 0.36 & $92 \cdot 5$ & $1 \cdot 61$ & 0.33 & 100 & $1 \cdot 55$ & $0 \cdot 35$ \\
\hline Weaning & $3 \cdot 51$ & 0.95 & $94 \cdot 1$ & $3 \cdot 73$ & $1 \cdot 07$ & 100 & $3 \cdot 61$ & $1 \cdot 01$ \\
\hline 4 weeks & $8 \cdot 10$ & $1 \cdot 96$ & $94 \cdot 8$ & $8 \cdot 54$ & $2 \cdot 27$ & 100 & $8 \cdot 31$ & $2 \cdot 11$ \\
\hline 8 weeks & $20 \cdot 76$ & $3 \cdot 86$ & $99 \cdot 3$ & $20 \cdot 90$ & 3.95 & 100 & $20 \cdot 83$ & $3 \cdot 88$ \\
\hline \multicolumn{9}{|l|}{ Growth rate (g/day) } \\
\hline Birth to weaning & 179 & 86 & $99 \cdot 4$ & 180 & 69 & 100 & 180 & 78 \\
\hline Weaning at 4 weeks & 164 & 47 & $95 \cdot 4$ & 172 & 53 & 100 & 168 & 50 \\
\hline 4 to 8 weeks & 452 & 95 & $102 \cdot 5$ & 441 & 99 & 100 & 447 & 97 \\
\hline
\end{tabular}

TABLE 2

The effect of intake of milk replacer during the suckling period, on subsequent reproductive performance (litter size)

Milk replacer

\begin{tabular}{lccccccc}
\multicolumn{3}{c}{ Without } & \multicolumn{3}{c}{ With } \\
Litter size & $\begin{array}{c}\text { No. of } \\
\text { litters }\end{array}$ & Mean & s.d. & litters & Mean & s.d. \\
Litter 1 & 21 & $9 \cdot 1$ & $2 \cdot 1$ & 16 & $10 \cdot 1$ & $1 \cdot 9$ \\
Litters 2 to 5 & 39 & $9 \cdot 0$ & $2 \cdot 5$ & 16 & $10 \cdot 4$ & $2 \cdot 6$ \\
All litters & 60 & $9 \cdot 1^{*}$ & $2 \cdot 3$ & 32 & $10 \cdot 3^{*}$ & $2 \cdot 3$
\end{tabular}


Although Op de Beck and Castaldo (1983), van der Steen et al. (1983) and van Rijen (1985) reported that the use of milk replacer during the suckling period could improve growth rate of piglets, none of these reports mentioned any difference in performance of male or female piglets, due to the intake of milk replacer during the first days of life.

From 51 female piglets of the group reared with milk replacer and 49 control piglets, the subsequent reproductive performance was analysed. There was no significant difference between the treatments either in the number of sows removed for reproductive reasons or in the reproductive results, except when all parities were taken into consideration: average litter size was 1.2 $(P<0.05)$ piglets higher for the sows reared with milk replacer (Table 2). However, these results should be treated with caution. However, in that so far, only 16 and 21 females reared with and without milk replacer, respectively, have produced a first litter.

Two of the eight commercial milk replacers tested showed insufficient solubility and preservation characteristics. Comparison of the average level of daily intake of the other milk replacers (no. $=51$ litters) showed that the intake itself can vary considerably, according to the kind of milk replacer: on the 1st day the average intake ranged from 15 to $40 \mathrm{ml} / \mathrm{day}$, and on the 7th day from 40 to $70 \mathrm{ml} /$ day. The total intake during the first 7 days of life, varied from 250 to $400 \mathrm{ml}$. Over $90 \%$ of all litters receiving milk replacer started drinking the 1st day after birth.

\section{CONCLUSION}

According to this experiment, the intake of milk replacer during the first 12 days of life has no effect on mortality. However, the use of milk replacer has a positive influence on growth rate of female piglets, and could in this way, influence their eventual reproductive performance. The intake of milk replacer itself varies considerably according to type.

\section{ACKNOWLEDGEMENTS}

We wish to thank the Institute for encouragement of Scientific Research in Industry and Agriculture (IWONL), De Crayerstraat 6, B-1050 Brussels, for subsidizing this research.

\section{REFERENCES}

Alsing, I. 1976. Untersuchungen über den Einfluss der maternalen Effekts auf die Heritabilität der Wurfrösse bei Sauen. Proceedings of the 27th Annual Meeting of the European Association of Animal Production, Zurich.

Csarnecki, R., Wejehsza, D. and Owsianny, J. 1986. Effect of the litter size in which young sows and boars were reared on their future reproductive performance. Proceedings of the Annual Meeting of The European Association of Animal Production, Budapest.

'Fowler, V. R. and Fraser, D. 1985. The effect of pre-weaning supplementary food on the growth of piglets after weaning at 25 days. Animal Production 40: 547 (Abstr.).

HAmpson, D. J. 1986. Alterations in piglet small intestinal structure at weaning. Research in Veterinary Science 40: 32-40.

Hartog, L. Den, Verstegen, M. and Everts, H. 1985 Recente ontwikkelingen op het gebied van zeugen/ baby voeding. Verslag Symposium, Pricor, Nieuwegein, pp. 74-85.

HEYDE, H. VAN DER 1983. Biggenopfok en vruchtbaarheid van de zeug na korte lactatierduur. Aggregaatsthesis, Faculteit van de Landbouwwetenschappen, Rijksuniversiteit Gent.

Heyde, H. van der and Lievens, R. 1982. L'influence de sevrage précoce et de la taille de la nichée élevée par le truie sur les performances d'engrassement et de reproduction du porcelet. Revue de l'Agriculture 35: 3195-3206.

HEYDE, H. VAN DER and LiEvens, R. 1984a. Effect of early weaning, fractionated weaning and litter size on subsequent reproductive performance of piglets. Results of Pig Research, I.W.O.N.L., Brussels, pp. 209-213.

HeYde, H. VAN DER and LiEvens, R. 1984b. Effect of early weaning, fractionated early weaning and litter size on ulterior reproductive performance of piglets. Proceedings of 35th Annual Meeting of the European Association of Animal Production, The Hague.

JoHANSSON, K. 1980. Some notes concerning the genetic possibilities of improving sow fertility. Proceedings of the 31st Annual Meeting of the European Association of Animal Production.

Miller, B. G., Newby, T. J., Stokes, C. R. and Bourne, F. J. 1984. Influence of diet on postweaning malabsorption and diarrhoea in the pig. Research in Veterinary Science 36: 187-193.

Op DE BeCK, M. and Castaldo, M. 1983. Méthode de nutrition et technique d'élevage des porcelets avec un aliment d'allaitement acide: intérêt technique de sone utilisation en complement de l'alimantation composée traditionelle. Bulletin de la Société Vétéinaire Pratique de France 67: (6), 1-16.

Revelle, T. And Robison, O. 1973. An explanation for the low heritability of litter size in swine. Journal of Animal Science 37: 668-675.

RiJen, M. van 1985. Aangezuurde kunstmelk voor biggen tijdens de zoogperiode. Proefverslag, Sterksel, No. 44.

RoBison, O. 1972. The role of maternal effect on animal breeding. Journal of Animal Science 36: 1305-1315.

STEEN, H. VAN DER 1985. Maternal influence mediated by litter size during the suckling period on 
reproductive traits in pigs. Livestock Production Science 13: 147-158.

Steen, H. van der, Hartog, L. Den, Groot, P. de and Roo, K. DE 1983. Landbouwhogeschool, onderzocht Porcomel. Boerderij/Varkenshoulderij 68: $14-15$. 